\title{
Chapter 13 \\ Exploring and Managing Adaptation Frontiers with Climate Risk Insurance
}

\author{
Laura Schäfer, Koko Warner and Sönke Kreft
}

\begin{abstract}
This chapter aims to inform the Loss \& Damage debate by analysing the degree to which insurance can be used as a tool to explore and manage adaptation frontiers. It establishes that insurance can be used as a navigational tool around adaptation frontiers in three ways: First, by facilitating the exploration of adaptation frontiers by contributing to a framework for signalling the magnitude, location, and exposure to climate-related risks and providing signals when adaptation limits are approached. Second, by supporting actors in moving away from adaptation limits by improving ex-ante decision making, incentivising risk reduction and creating a space of certainty for climate resilient development. Third, by aiding actors in remaining in the tolerable risk space by facilitating financial buffering as part of contingency approaches. However, we also find that insurance against the risks of climate change in market terms possesses several limitations. We therefore suggest the embedding of insurance in a comprehensive climate risk management approach accompanied by other risk reduction and management strategies as key principle for any international cooperation approach to respond to climate change impacts.
\end{abstract}

Keywords Loss \& Damage $\cdot$ Resilience $\cdot$ Climate risk insurance Comprehensive climate risk management

\subsection{Introduction}

The idea of adaptation to climatic stressors has emerged as a mainstream risk management strategy to help maintain human-ecological systems in a "safe operating space" (Röckström et al. 2009). However, emerging literature underpinning

L. Schäfer $(\varangle) \cdot$ S. Kreft

Munich Climate Insurance Initiative (MCII) hosted by United Nations University-Institute for Environmental Security (UNU-EHS), Bonn, Germany

e-mail: schaefer@ehs.unu.edu

K. Warner

United Nations Climate Change Secretariat (UNFCCC), Bonn, Germany

(C) The Author(s) 2019

R. Mechler et al. (eds.), Loss and Damage from Climate Change, Climate Risk

Management, Policy and Governance, https://doi.org/10.1007/978-3-319-72026-5_13 
Chaps. 16, 17, and 19 of the IPCC 5th Assessment report (Klein et al. 2014; Chambwera et al. 2014; Oppenheimer et al. 2014) point towards limits in the ability of systems to adapt to climate stressors (Dow et al. 2013a, b; Warner et al. 2013; Adger et al. 2009). There is evidence that poor and vulnerable people and communities already exist and persist at the edges of these boundaries and limits (Islam et al. 2014; Warner et al. 2015; Monnereau and Abraham 2013). They find themselves operating within an adaptation frontier, a "socio-ecological system's transitional adaptive operating space between safe and unsafe domains" (Preston et al. 2014). To successfully navigate adaptation frontiers, these people and communities need tools that allow them to explore the frontier, stay away from adaptation limits and continuously move into safer domains.

As the debate around adaptation constraints, limits, and possible associated losses and damages unfolds, insurance has been promoted as a tool that can help buffer against the disruptive effects of climate variability and climate change (see chapter by Linnerooth-Bayer et al. 2018 in this book; Surminski et al. 2016). Insurance has been a cornerstone in climate impact related discourses of the United Nations Framework Convention on Climate Change (UNFCCC) from its establishment in 1992. Several substantive policy proposals were brought forward resulting in insurance being featured in relevant adaptation and Loss and Damage related decisions and frameworks (compare chapters by Mechler et al. 2018; Linnerooth-Bayer et al. 2018; Schinko et al. 2018 in this book). Insurance is now anchored in major policy arenas as one tool to address the risk of climate change, including the Paris Agreement and the Sendai Framework for Disaster Risk Reduction. Additionally, the topic experienced a boost through the G7's decision to set up a "Climate Risk Insurance Initiative" (InsuResilience) during their 2015 summit in Elmau and the 2017 G20 summit acknowledging a "Global Partnership for Climate and Disaster Risk Finance and Insurance Solution” (G7 2015; G20 2017).

Drawing on research undertaken in the context of the G7 InsuResilience Initiative to assess the potential of insurance to improve risk management for poor and vulnerable communities (Schäfer et al. 2016), this chapter aims to inform the Loss and Damage debate by analysing the degree to which insurance can be used as a tool to explore and manage adaptation frontiers. In a first step, we outline the challenges related to decision making under climate risk and introduce the concept of adaptation frontiers. In a second step, we analyse how decision makers can use insurance in a way to address these challenges and manage adaptation frontiers. In a third step, we discuss limits of insurance as a climate risk management tool and describe principles that enable insurance tools to help move poor and vulnerable people and countries away from adaptation limits into a safer, tolerable risk space.

The chapter concludes that insurance can be used as a navigational tool around adaptation frontiers in three ways: First, by facilitating the exploration of adaptation frontiers by contributing to a framework for signalling the magnitude, location, and 
exposure to climate-related risks and providing signals when adaptation limits are approached. Second, by supporting actors in moving away from adaptation limits by improving ex-ante decision making, incentivising risk reduction and creating a space of certainty for climate resilient development. Third, by aiding actors in remaining in the tolerable risk space by facilitating financial buffering as part of contingency approaches. However, in order for risk transfer instruments like insurance to approach their potential as risk management tool in developing countries, seven Pro-Poor Principles for climate risk insurance need to be met.

\subsection{Decision-Making Under Climate Risks}

At the beginning of the 21st century, human activities, primarily their fossil fuel use, have the potential to irreversibly damage the Earth's climate system and transform it rapidly into "a state unknown in human existence" (Barnosky et al. 2012). Science suggests that climate change will cause changes in the "frequency, intensity, spatial extent, duration, and timing of extreme weather and climate events" as the IPCC Special Report on Extreme Events (SREX) concludes (IPCC 2012). This change in climate will lead to "more rapid, larger and more unpredictable changes in risks than have been experienced in the past" (Ranger and Fisher 2012).

Risk is both an analytical and a normative concept. It can be understood as the combination of the probability of an event and its consequences that harm things which human beings value (Klinke and Renn 2002). With the ultimate objective to maintain risks for valued things at a tolerable level, actors apply risk management strategies. They help to identify and evaluate risks, select measures to avoid and prevent them from happening but also to plan for responding and recovering from actual impacts. Risk management measures are used to control risks for things humans value-e.g. livelihoods, ecosystems, cultural assets "with the explicit purpose of increasing human security, well-being, quality of life, and sustainable development" (IPCC 2014). The idea of adaptation to climatic stressors has emerged as a mainstream risk management strategy to help maintain human-ecological systems in a "safe operating space" (Röckström et al. 2009). Effective adaptation means integrating climate change related risks into actors' existing decision-making processes with the aim of maximising the long-term value of today's decisions (Bouwer and Aerts 2006). This includes risk evaluation as a first step to assess potential risk to social objectives and values followed by the decision which risk to actively manage and which not. 
Box 13.1 Barriers and limits to adaptation through the lens of risk preferences. Assuming that risk tolerance is socially constructed, Klinke and Renn (2002) suggest that actors evaluate risks based on one of three categories according to which they decide if the risks need to be managed or not: acceptable, tolerable, and intolerable. Acceptable risks are low-complex, well understood risks that are deemed so low that no additional efforts for risk reduction are justified (ibid). Tolerable risks relate to "activities seen as worth pursuing for their benefit" (Dow et al. 2013a) but where additional efforts to risk reduction are required to keep risk within reasonable levels. Dow et al. (2013a) describe how the scope of risks that fall within this area is heavily influenced by adaptation opportunities and constrains and therefore the categorisation of risks varies spatially, jurisdictionally, and temporally. Constraints may limit the range of available adaptation options creating the potential for residual damages for actors, species, or ecosystems. Within the tolerable risk space, the risk of residual damage may be viewed as an acceptable or tolerable trade-off under some circumstances (de Bruin et al. 2009). Intolerable risks go beyond socially negotiated norms and values although adaptation action has been taken (Dow et al. 2013a). At this stage, adaptation options that are practical or affordable to keep valued social objectives or goods within the norm are no longer available. These risks represent threats to core social objectives regarding health, welfare, security, or sustainability (Klinke and Renn 2002; Dow et al. 2013a).

Emerging literature underpinning Chaps. 16, 17, and 19 of the IPCC 5th Assessment report point towards limits in the ability of systems to adapt to climate stressors (Dow et al. 2013a, b; Warner et al. 2013; Adger et al. 2009). Adaptation limits-for example "soft limits" related to institutions and planning processes, and "hard limits" relating to physical characteristics of a system-constitute a point at which existing adaptation options can no longer protect the objectives and needs of actors and systems against intolerable risks (Adger et al. 2009; see also Mechler and Schinko 2016; introduction by Mechler et al. 2018 and chapter by Schinko et al. 2018 in this book). At the limit between tolerable and intolerable risk, the risk must either be accepted, the objective itself must be abandoned, or adaptation must be transformative to avoid intolerable risk (Dow et al. 2013a). Figure 13.1 depicts acceptable, tolerable and intolerable risks, separated by limits of acceptable risk and adaptation limits. The turning space before an adaptation limit is reached, can be described as an adaptation frontier. Preston et al. (2014) define it as the "domain between a socio-ecological system's safe operating space and its unsafe operating space". The adaptation frontier is a domain where feasible and affordable adaptation action is still available and has the potential to secure objectives and needs of actors and systems (ibid.) However, the frontier is characterised by uncertainty if the available option is used in an efficient and timely manner which is needed to stay away from adaptation limits (Dow et al. 2013a).

According to Preston et al. (2014) and underpinning literature (Mechler and Schinko 2016; chapter by Schinko et al. 2018 in this book) adaptation can offer two types of benefits to systems on the frontier: On the one hand, reducing the vulnerability of systems to move them away from the edge of the frontier. On the other hand, enhancing resilience, enabling systems to persist despite the continued pres- 


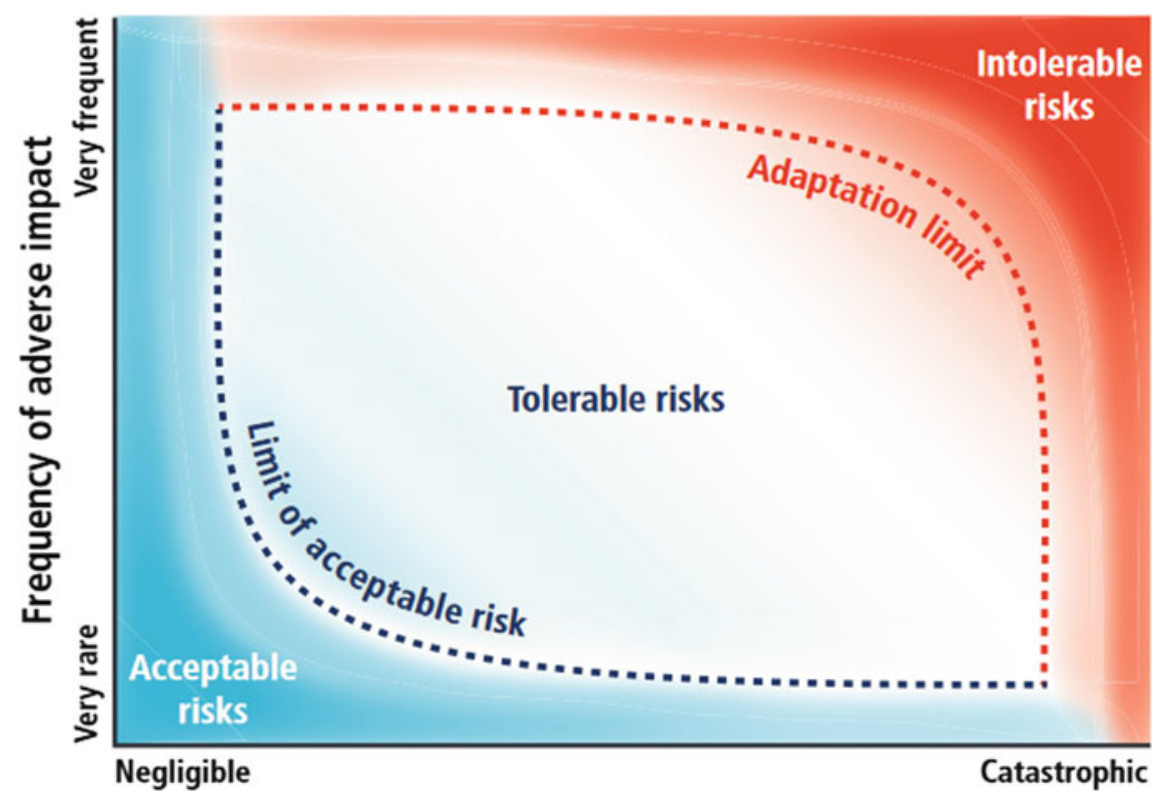

Fig. 13.1 Acceptable, tolerable and intolerable risk. Source Dow et al. (2013a)

ence of and exposure to pressures. In the face of potentially growing weather extremes and profound shifts in natural systems driven by climate change, all countries will require pathways that reduce vulnerability and lead to a more climate resilient development. These strategies should complement and facilitate the design of approaches to address longer-term incremental adverse effects of climate change. Increasing comprehensive risk management capacity for dealing with today's extreme climaterelated events can provide the basis for managing both current climate variability and long-term shifts in climate patterns. Climate resilient sustainable development pathways run along a spectrum of those things decision makers can plan for and pre-empt, complemented by a suite of contingency measures to help manage climate risks and impacts that have not been accounted for or addressed through planning and risk reduction. This chapter argues that insurance has a role to play across this spectrum.

\subsection{Insurance Related Instruments as Navigation Tools for Adaptation Frontiers}

Insurance is the transfer of risk of a loss from one entity to another in exchange for a payment which is called premium. The insured person (policyholder) is trading the possibility of a loss for a guaranteed cost to a risk taking entity (the insurer). Insurance 
works by pooling losses, transferring risk of fortuitous losses and indemnification (Rejda and McNamara 2017). By spreading risks among people and over space and time, insurance-related tools allow to collectively manage losses that would overwhelm individual members of a group, limiting the need for members to take costly individual action. In this arrangement, the premium replaces the "uncertain prospect of losses with the certainty of making small, regular premium payments" (Churchill 2006). In case of a loss which is covered by the insurance policy, the insured holds the right to claim compensation.

Based on these principles, disaster risk insurance is a facilitative mechanism which provides post-disaster financial support against the loss of assets, livelihoods, and lives at an individual, community, national, and regional level. "Climate risk insurance" refers to a special type of disaster insurance, covering losses and damages caused by extreme weather events, which are intensified and increased in frequency by climate change. Climate risk insurance schemes may be both direct and indirect. Direct insurance approaches are those in which the insured benefits directly from transferring risk to a risk taking entity (such as an insurer). In the event the insurance agreement is triggered, the insurance payout is directly transferred to the insured. Indirect insurance approaches are those where the final intended target group benefits indirectly from payments intermediated by an insured government or from being a member of an institution that has insurance (Schäfer et al. 2016; see also chapter by Linnerooth-Bayer et al. 2018 in this book).

This chapter argues that insurance can support people and communities on the frontier of adaptation in several ways, helping them in

- exploring adaptation frontiers by contributing to a framework for signalling the magnitude, location, and exposure to climate-related risks and providing signals when adaptation limits are approached;

- moving away from adaptation limits by improving ex-ante decision making, incentivising risk reduction and creating a space of certainty for climate resilient development;

- remaining in the tolerable risk space by facilitating financial buffering as part of contingency approaches when climate-related risks exceed current capabilities to manage.

In the following, the different roles of insurance in exploring and managing adaptation frontiers are described in detail. It has to be noted, however, that transferring risks in a cost-efficient way through insurance is only one step in a systematic process. The effective management of adaptation frontiers, aimed at enabling climate-resilience development, requires a comprehensive approach to risk management. This approach should involve a portfolio of actions aimed at improving the understanding of disaster risks, reducing and transferring risk as well as responding to and recovering from events and disasters - as opposed to a singular focus on any one action or type of action (see Fig. 13.2). 


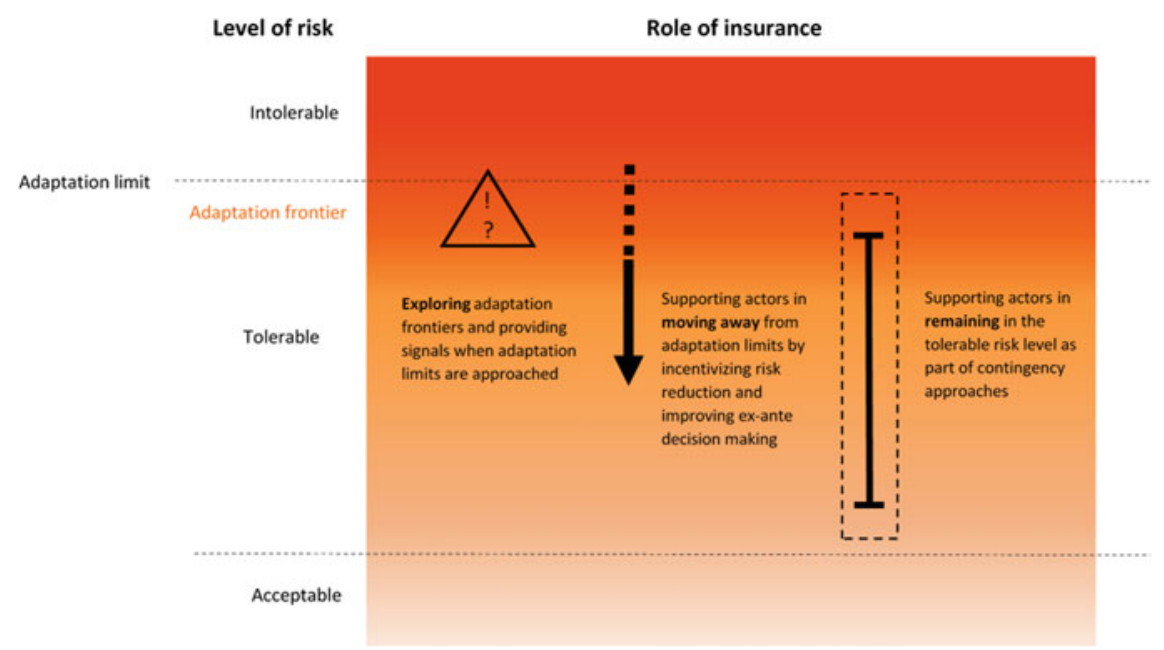

Fig. 13.2 The role ofinsurance in managing adaptation frontiers. Source Author's own

\subsubsection{Insurance as Part of a Risk Signalling Mechanism}

To be able to make informed decisions in a world of increasing climate risks, actors need to explore adaptation frontiers. Therefore, countries and people need reliable information about the magnitude, location, and exposure to climate-related risks as well as signals to determine their leeway regarding adaption limits. Risk transfer tools like insurance can support risk signalling mechanisms in the following two ways.

Catalysing Risk Assessment to Signal the Magnitude, Location and Exposure to Climate-Related Risks

Assessing the risk of losses and damages is a prerequisite for identifying needs and policy priorities. Risk assessment brings attention to the hazard potential, the exposure and vulnerability, and in this way it can raise awareness and expose new options for managing the risks (Warner and Spiegel 2009). Publicly collected and open source data and risk assessments, as well as open source hazard modelling, can contribute meaningfully to national and regional risk-management and investment decisions. However, risk assessments are often not performed in developing countries (Collier et al. 2009). Being the precondition for calculating premium levels for policyholders, risk assessment is a vital part of insurance. Accordingly, insurance can be one way to facilitate regional and international data analysis - such as establishing data standards, methods and data repositories - and can therefore be a catalyst for risk assessment. Thereby, insurance-related tools can help set up a framework for signalling the magnitude, location, and exposure to climate-related risks.

At country level, the African Risk Capacity's (ARC) risk modelling and early warning software platform, Africa RiskView, uses satellite-based data to estimate 
the impact of weather events on vulnerable populations - and the response costs required to assist them-before a hazard season begins, and as it progresses. This instrument provides the hard triggers for ARC's insurance mechanism. But it also allows countries to monitor and analyse rainfall throughout the continent and estimate the impact of weather developments on vulnerable populations in-season, "thus providing ARC Member States and Partners with an innovative early warning tool" (ARC 2015). At micro level we find plenty examples where weather data was collected together with policy holders (e.g. through rain gauges) during the design and set up process of insurance products. This data ultimately contributed to increasing farmers' sensitivity to changing rainfall patterns and helping them develop a better understanding of the likely impact of weather on yields (Sharoff et al. 2015; Hellmuth et al. 2009).

Limits of Insurability as Means to Signal When Adaptation Limits Are Approached In the context of increasing climate risk, the concept of insurability plays an important role. Vulnerability to rising climate change risks is not only of importance to people but also the insurance industry is vulnerable to rising risks. Increasingly catastrophic losses made private insurance companies in developed countries pull out of some markets, making insurance unavailable for affected households (Botzen and van den Bergh 2008). Herweijer et al. (2009) therefore conclude that "climate change has the potential to threaten the widespread availability and affordability of insurance for people and their property in many regions, that is, the insurability of the risk." Stahel (2003) defines the concept of insurability as the "natural borderline" between the market economy and nation states: risks that cannot be insured need not to be legislated; uninsurable risks, however, have to be dealt with by nation states." Thereby, increasing limits of insurability can provide a strong signal that actors or systems reached the upper end of adaptation frontiers, existing on the edge of adaptation limits. This information could incentivise large scale governmental action to effectively reduce risk and increase insurability in a way that wouldn't be feasible or affordable for individual actors.

\subsubsection{Improving Ex-Ante Decision Making with Insurance}

Increasing risk of extreme weather events driven by climate change strengthen the need for a more forward-looking approach to disaster risk management, with greater focus on reducing risk before a disaster strikes (Ranger and Fisher 2012). Moving away from purely ex-post responses, actors need to manage risk proactively, before a disaster strikes. This includes reducing risk ex-ante and building long-term resilience against extreme weather events.

\section{Price Signals as Means to Incentivise Risk Reduction?}

Insurance can play a role as messenger of climate change impacts through its terms and price signals. Insurance companies have an incentive to 'risk price' as much as possible so that they can accurately predict the probability of a claim, and the 
likely cost of that claim. Through the technical risk pricing of contracts, insurance can provide valuable information for societal and economic actors in understanding the risks and how risk cost may be changing. When the risk is priced correctly "the price itself indicates the risk level, which can help people and firms make betterinformed decisions about risk taking and risk mitigation investments" (Ranger and Fisher 2012). In an ideal scenario, insurance thereby incentivises risk reduction behaviour, e.g. by making it a prerequisite for reducing premiums or providing the option for people to work for their insurance cover by engaging in communityidentified projects to reduce risk and build climate resilience. In this way, insurance could contribute to preventing losses and damages. In a theoretical example, the high costs of insurance against flood would provide an incentive for an actor, wanting to buy a house in a flood prone area, not to buy. Instead, if investing into risk reduction measures directly, this leads to a reduction in premium price and insurance might provide a strong incentive for the actor to invest into risk reduction activities. In this way "insurance can create powerful incentives for people to manage their risk better and reduce losses" (ibid.). However, the evidence on actual insurance schemes incentivising risk reduction is weak. Surminski and Oramas-Dorta (2013) found that only a few already existing schemes show an operational link between risk transfer and risk reduction (Surminski and Oramas-Dorta 2013). Chambwera et al. (2014) moreover show that local and state regulations might undermine incentives to decrease risks, for example by prohibiting fully risk adequate insurance rates.

A Space of Certainty Allowing for Improved Ex-Ante Planning and Decision Making Insurance-related approaches, in combination with a wide range of others at local, national, regional and international levels, can contribute to creating a space of certainty within which improved ex-ante decision making is possible (Skees et al. 2008; Hoppe and Gurenko 2006). By creating a secure investment environment, insurance instruments can enable productive risk-taking on the part of individuals and governments, and in this way contribute to mitigating disaster-induced poverty traps and foster climate-resilient development.

To limit their exposure, poor households often try to avoid risks. Therefore, they choose activities with lower risk, but also lower returns, and forego income opportunities (Cole et al. 2012). Researchers observed in Tanzania that poorer farmers grew more sweet potatoes (which is a lower-risk, lower-return crop) than richer farmers - resulting in a reduction of up to $25 \%$ average earnings (Dercon 1996). To be prepared in the event of a shock, the poor also tend to diversify their incomegenerating activities, assets or choice of crop or accumulate precautionary savings. While this is certainly a sensible measure to decrease risk, it can also lead to a loss of profits as people cannot afford to specialise in the more profitable options. In general, these informal strategies to manage climate risk usually cover only a small proportion of the loss, so "the poor have to patch together support from various sources" (Churchill 2006). By reducing the residual risk that could not be reduced by measures already taken, insurance can help lessen financial repercussions of volatility and, in the longer-term, help people to adapt to climate change. Insurance represents predictable and manageable costs - the insured party does only pay the insurance 
premium instead of risking unmanageable costs due to disaster losses. These predictable costs and the security of a payout in case of a disaster create a space of certainty and allow for longer-term planning, investment and development activities. Thereby, insurance can incentivise "positive risk taking" (Mobarak and Rosenzweig 2013), which is essential for innovation and growth. There are first indications that at the micro level, insurance can help to unlock opportunities and may help increase savings, increase investments in higher-return activities and improve credit worthiness (see e.g. Jensen et al. 2015; Cai et al. 2015; Madajewicz et al. 2013; Luxbacher and Goodland 2010). At the macro level, research suggests that insurance may contribute to economic growth by allowing for more effective risk management (Lester 2014; von Peter et al. 2012; Melecky and Raddatz 2011).

We also see that the way risks are currently managed in developing countries is often not effective. The mainly ex-post risk management strategies are not timely and can lead to financial burdens as well as volatility and uncertainty in decisionmaking. They can ultimately threaten the resilience of poor and vulnerable people, (re-)enforce poverty cycles and impede sustainable development. At the political level we find indications that insurance could help countries to reshape the ways in which risks are managed ex-ante. This can be facilitated by eligibility criteria that insurance companies can define as a precondition for people and countries wanting to purchase their products. These criteria can foster the selection of nationally appropriate risk reduction priorities, and help develop a culture of prevention and resilience. For example, we find indications that requesting contingency planning as eligibility criteria for the ARC has influenced the process of disaster relief programmes in the relevant countries, shifting paradigms away from crisis to risk management. ARC Member States currently pay insurance premiums through national budget processes and receive payouts only for pre-approved contingency plans. Before the countries are allowed to buy ARC insurance policies, they have to submit contingency plans, defining how the money will be used in case of a payout. ARC supports the countries in developing the contingency plans with in-country capacity-building programmes (ARC 2015). By providing incentives for governments to invest in their emergency planning and response capacities, ARC could contribute to shaping a culture of data-driven, prevention-focused risk management in their member countries in the long-term.

However, we have to be cautious about drawing conclusions from these first indications both at micro and macro levels. Evidence with regard to the impact of insurance is scarce as most schemes are still in their early stages of implementation. So far, most of the research is based on small case numbers, the cases and the results being highly context specific. Constant analysis and long-term monitoring and evaluation of project outcomes will be crucial to track potential impacts of insurance in the years to come. We also need to note that in all of the cases examined, it was not insurance alone but the interplay of insurance with other risk management activities and social protection tools that improved opportunities and created incentives. Without this relationship, supporting investment in higher-risk activities might also lead to maladaptation by encouraging people to undertake activities that should be avoided when considering longer-term climatic impacts. This "false sense of 
security" (Surminski and Oramas-Dorta 2013) might reduce the urgency for risk prevention and reduction, and thereby increase vulnerability to extreme events.

\subsubsection{Insurance as a Support Tool for Actors to Remain in the Tolerable Risk Space}

Effectively managing increasing climate change risk is a precondition for actors to remain within the tolerable risk space (Mechler and Schinko 2016). Insurance can support risk management strategies ex-post as safety net and buffer for people and countries, particularly for low frequency and moderate to high severity risks.

\section{Providing a Safety Net and Buffer: Insurance as Part of Contingency Strategies} Contingency strategies, managing unexpected shocks from climate stressors which could not have been reasonably anticipated through pre-emptive actions, can provide a key means for actors to remain within the tolerable risk space. These strategies are needed, in addition to planning and pre-emptive undertakings, as some climaterelated impact are unforeseeable at the time of planning or the magnitude of climaterelated impacts might surpasses estimates. Also, in cases where unforeseen impacts or costs arose from transboundary climate change impacts or responses or impacts were foreseeable, but response actions were economically or technologically unfeasible at the time of planning, contingency approaches are necessary. The strategies should complement and facilitate approaches to address longer-term incremental climate impacts, risks, and vulnerabilities associated with climate change.

Insurance plays an important role as part of contingency strategies. By providing timely finance that improves financial liquidity shortly after a disaster, insurance can play a role as a safety net and buffer for people and countries shortly after an event (Warner et al. 2012). Under these circumstances, insurance can help the insured to better absorb shocks, as they may not have to resort to coping strategies that might impede sustainable development (Okonjo-Iweala and Thunell 2015). Timely and reliable payouts enable households to protect their livelihoods when a disaster strikes: It can help individuals to cover losses and damages, stabilise their income, purchase food and other necessities and avoid costly asset depletion, ultimately allowing people to choose alternative means of coping with negative shocks (Dercon et al. 2005; Barrett et al. 2007; Skees and Collier 2008). There is significant evidence that insurance tools can help people to reduce distress asset sales and to increase food security, both enabling faster recovery after a shock (Greatrex et al. 2015; Bertram-Hümmer and Kraehnert 2015; Reyes et al. 2015; Janzen and Carter 2013). Based on the timely finance, insurance can also help to avoid business interruptions and fiscal deficits and post disaster loans (e.g. CCRIF SPC 2010). By reducing the residual risk that could not be reduced by measures already taken, insurance can help lessen financial repercussions of volatility and, in the longer term, help people to adapt to climate change. Insurance is an adaptation measure when it reduces the burden of climate impacts, risks, and vulnerabilities, if not the average loss (Linnerooth-Bayer et al. 2010). 
The given examples clearly illustrate how quick and sufficient payouts are key for insurance to realise its potential within a contingency strategy. A poorly designed insurance product that neither covers a sufficient amount of the damage nor provides incentives for risk reduction behaviour might lead to perverse incentives and increases the risk of people slipping (back) into poverty or staying poor. Although we find sufficient examples for quick payouts, there are also cases to be found where timely finance could not be provided by insurance products due to different reasons. Moreover, on the macro level, a fast payout to a government doesn't necessarily convert in timely support for the ultimate beneficiaries, being reliant on slow external processes, for example a sedate humanitarian system. Hence, constantly monitoring errors and challenges as well as learning from them to improve processes is crucial for the success of risk transfer tools like insurance as part of contingency strategies in the long-term.

\section{Insurance for Low Frequency and Moderate to High Severity Risks}

There are different layers of risks that risk management measures need to respond to. An efficient risk management system involves assigning an instrument or set of instruments to each layer, consistent with the selected strategy (reduction, retention or transfer). Financial instruments, in combination with risk prevention and reduction measures, should be selected on the basis of frequency and severity of disasters. This suggests that for weather-related risks which happen often (high frequency) but which are less serious (low severity), preventative and risk reduction activities may be the most cost-effective. The costs of preventing these events are typically much lower than the losses that would occur without investments in prevention measures. Alternatively, prevention measures for high-impact, low-frequency events can be far costlier with respect to the losses prevented. These more severe and less frequent risks, which cannot be reduced in a cost-effective manner, could be transferred to private and public insurance markets. Evidence from developed countries shows that insurance instruments have been effective in providing financial compensation for losses from extreme events to avoid the distress caused by the financial aftermath without financial protection (Arent et al. 2014). However, it is important to note that despite adaptation strategies, climate change may bring some residual risks which cannot be transferred to the insurance market cost-efficiently (Warner et al. 2012). Governments also need to adopt approaches to address these residual risks, "the losses and damages that remain once all feasible measures (especially adaptation and mitigation) have been implemented" (ibid). The following Fig. 13.3 illustrates a risk-layering strategy on the basis of the frequency and severity of the event (see also chapter by Schinko et al. 2018). 

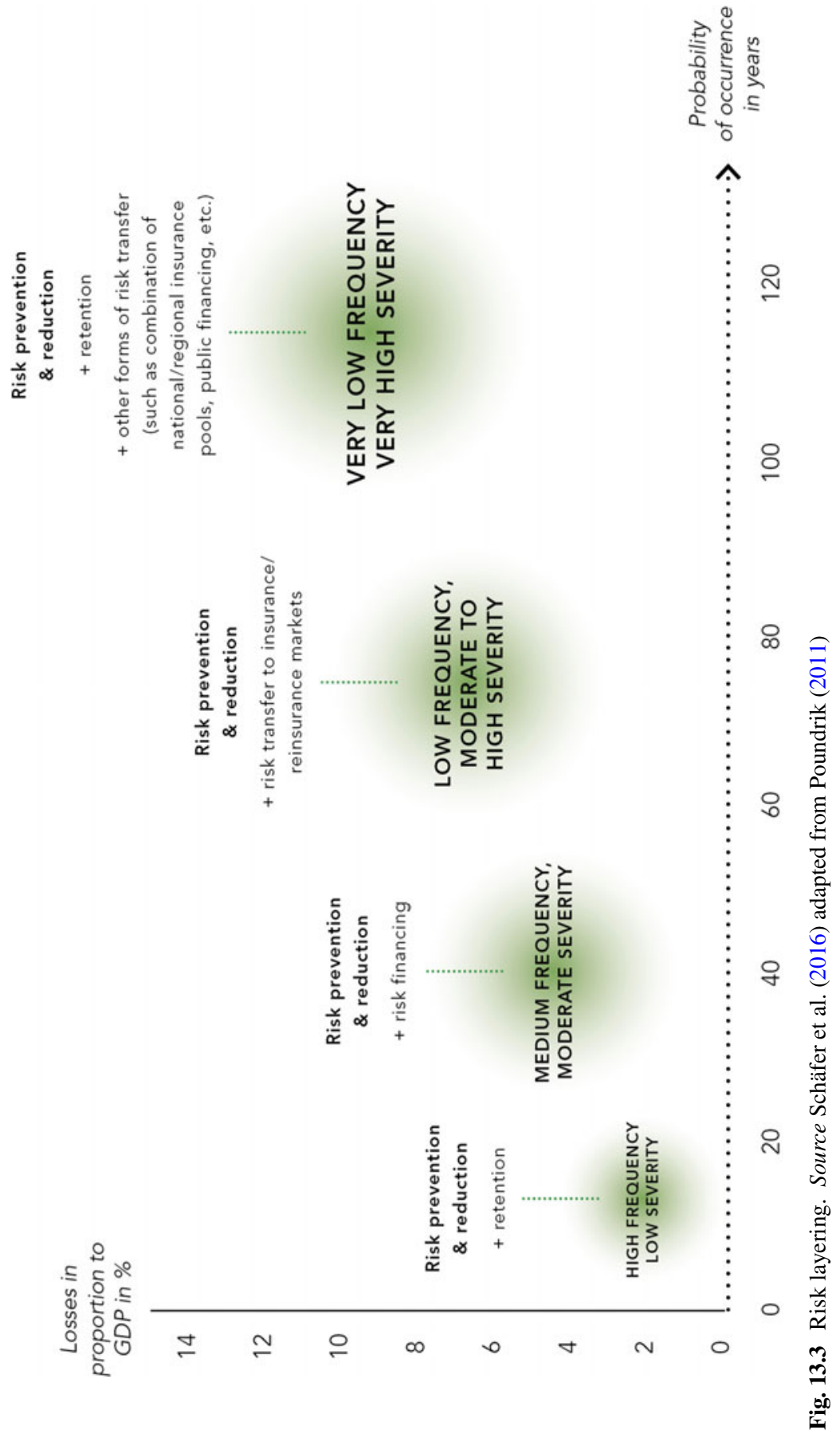


\subsection{The Need for Comprehensive Risk Management and the Limits of Insurance: Seven Principles to Design Effective Pro-poor Insurance Products}

Section three elaborated on how decision makers can use insurance tools to explore and manage adaptation frontiers. However, in the context of comprehensive planning and pre-emptive activities to manage climate risks, insurance is not a universal remedy for all types of climate impacts, risks, and vulnerabilities associated with climate change. It has limitations with regard to its applicability for some type of risks as it cannot cover all losses and climate change may pose a threat to insurability. These limitations have led to one of the most important insights for how this tool can contribute to addressing the adverse effects of climate change: Insurance should always be embedded in a comprehensive climate risk management system with a focus on risk reduction, and ex-ante planning. A combination of measures that include insurance can reduce maladaptation, and reduce immediate losses and long-term development setbacks from adverse climatic impacts. But beyond comprehensive risk management, there are other factors that need to be met in order for insurance tools to effectively support the risk management efforts of developing countries, a team from the Munich Climate Insurance Initiative (MCII) found. After having dealt with the limits of insurance, this section will describe these factors in detail.

\subsubsection{Limits of Insurance}

Experience reveals multiple limitations of traditional forms of insurance (Hoff et al. 2005): it is not applicable for all types of risks, does not prevent or reduce the likelihood of direct damage and fatalities from extreme weather events and does not cover all losses. Potential un-insurability associated with increasing frequency and magnitude of extreme weather events poses an additional limitation. Moreover, it is not always the most cost-effective or affordable approach and actor's behaviour towards low probability, high impact events can make the application of insurance approaches challenging.

Insurance Is Not an Appropriate Measure for All Types of Risks

Insurance options can support adaptation and risk resilience for extreme weather events, but are not appropriate for many, usually slower-onset, climate-induced impacts, that happen with high certainty under different climate change scenarios. The losses from long-term, foreseeable risks, such as sea-level rise, desertification and the loss of glaciers and other cryospheric water sources, are estimated to be substantial in the future (IPCC 2012). Even for weather-related events, insurance would be an ill-advised solution for disastrous events that occur with very high frequency, 
such as recurrent flooding. Resilience-building and prevention in such instances may be cost-effective ways to address these risks.

Insurance Cannot Cover All (Types of) Losses

Insurance can only cover a percentage of losses, and even when policies are in place to offer coverage, basis risk can result in farmers being less protected than they expected to be. Basis risk can be understood as the risk that insurance claims do not adequately reflect the losses incurred; in other words, an individual suffers a loss and does not receive a payment for it because the insurance threshold was not triggered. In this way, even households that are fully insured end up bearing a significant amount of uninsured risk. This is particularly a problem for weather index insurance products (which currently make up the bulk of climate risk insurance schemes) as they pay based on the measure of weather or area yields.

Additionally, we have to note that not all types of losses and damages can be expressed in monetary terms. Insurance cannot address these types of non-economic losses and damages - context-dependent types of losses that don't have market price and cannot be easily given a monetary value. For example, there is no payout that could compensate for the loss of culture, identity or biodiversity, all of which may be results of climate change related events.

\section{Climate Change May Make Some Risks Uninsurable}

As climate change will increase the intensity and frequency of extreme weather events, there may come a time when some risks become so severe that they are uninsurable. An increased risk for currently insurable perils, such as crops and livestock, will lead to higher premiums, which might ultimately make the product too expensive for the poor and the actors who pay premiums on behalf of them.

One determinant of increasing premiums is the rising uncertainty about climate related risks. To assess risks and calculate premiums, the insurance industry relies on weather data which are so far based on historical records of hazard occurrences (Herweijer et al. 2009). However, climate change projections include a high level of uncertainty as besides predicting impacts of future extreme events, anticipating future vulnerability, socioeconomic trends and the way complex systems might react to new stressors is challenging (Ranger and Niehoerster 2012). This leads to greater uncertainties of insurers about the frequency and magnitude of future claims. Science indicates that the greater the uncertainty of the probability of an event and the magnitude of losses, the greater will be the insurance premium charged (Kunreuther 1996). However, if premiums "necessary to cover a disaster in a climatically changed world are greater than homeowners and businesses are willing or able to pay, the private insurance market will collapse" (Cousky and Cook 2009). On the other side, if insurers under-price risks, the accumulation of capital may be inadequate to cover losses threatening the solvency of insurers (Herweijer et al. 2009). Insurers therefore have to adjust in particular their underwriting practices that are mostly based on immediate past experience.

It is not known how the private markets would react to rising risk levels in the future, particularly in developing countries. Cousky and Cook (2009) point to the fact that "if risk is increasing over time, such that insurers do not believe they can 
accurately estimate expected losses, a key condition of insurability is violated." Kunreuther and Michel (2008) therefore conclude that only a requirement by law will make insurers provide coverage for climate-related risk that have a high enough potential for causing catastrophic losses in specific areas.

\section{Behavioural Factors: Why People Don't Insure Against Big Risks}

It has often been observed that homeowners don't purchase disaster insurance. While budget constraints are one explanation for this behaviour, another explanation is people's tendency to understate the probability of a rare events and catastrophes for themselves. Kunreuther and Pauly (2004) could show that "people don't insure against low-probability high-loss events even when it is offered at favourable premiums." Due to a pre-disaster "It will not happen to me" perception, people don't feel the need to voluntarily purchase insurance coverage (Hertwig et al. 2004). Kousky and Cooke (2012) conclude that "homeowners, facing a budget constraint and a constraint that their utility with insurance exceeds that without it, may find the required loadings too high to make insurance purchase an optimal decision."

\subsubsection{Seven Principles to Design Effective Pro-poor Insurance Solutions}

This chapter is based on the observation that poor and vulnerable people and communities already exist and persist at the edges of adaptation limits, operating within adaptation frontiers. To successfully navigate adaptation frontiers, these people and communities need tools that allow them to explore the frontier, stay away from adaptation limits and continuously move into safer domains. So far, this chapter established that insurance can be used as a navigational tool around adaptation frontiers, however has limits that have to be taken into account when applying insurance instruments. Based on these findings, the final part of the chapter examines success criteria for instruments like insurance to approach their potential as risk management tool in developing countries.

In describing these success criteria we make use of an analysis of 18 existing insurance schemes with regard to success factors and challenges for climate risk insurance for the poor and vulnerable, conducted by a team from the MCII. Based on this analysis, the MCII team distilled seven Pro-Poor Principles for Climate Risk Insurance (Schäfer et al. 2016). The principles can aid decision makers and practitioners in reaching poor and vulnerable people with effective insurance solutions. They can guide the design process of new insurance schemes that target the poor and vulnerable in particular by following the suggested steps or help with the identification of existing insurance schemes to be supported by climate risk insurance initiatives. Additionally, the principles can be used to support climate risk insurance practitioners in assessing and/or improving their current operations. The principles are described in Box 13.2 and further discussed below. 


\section{Box 13.2 Seven Pro-Poor Principles for Climate Risk Insurance}

1. Facilitating comprehensive-needs based solutions: Solutions to protect the poor from extreme weather events must be tailored to local needs and conditions. It is imperative to embed insurance in comprehensive risk management strategies that improve resilience.

2. Offering Client value: Providing reliable coverage that is valuable to the insured is crucial for the take-up of insurance products.

3. Ensuring Affordability: Measures to increase affordability for poor and vulnerable people are paramount to the success of an insurance scheme and also important to satisfy equity concerns.

4. Maximising accessibility: Efficient and cost-effective delivery channels that are aligned with the local context are key for reaching scale.

5. Allowing for Participation, Transparency \& Accountability: Successful insurance schemes are based on the inclusive, meaningful and accountable involvement of (potential) beneficiaries and other relevant local-level stakeholders in the design, implementation and review of insurance products, creating trust and providing a basis for local ownership and political buy-in.

6. Generating Sustainability: Safeguarding economic, social and ecological sustainability is crucial for the long-term success of insurance schemes.

7. Creating an enabling environment: It is vital to actively build an enabling environment that accommodates and fosters pro-poor insurance solutions.

\section{Comprehensive, Needs Based Solutions}

The poor and vulnerable face multiple risks that get in the way of opportunities to reduce poverty. For many of the analysed insurance schemes, the key to success has been offering comprehensive solutions to mitigate weather risks. Three important factors were identified in the analysis of 18 existing insurance schemes: (1) implementing risk, needs, demand and context assessments, (2) linking insurance to ex-ante climate risk management, and (3) fostering locally driven and owned schemes (Schäfer and Waters 2016). The Rural Resilience Initiative (R4) is a good example for this principle. R4 currently reaches more than 37,000 farmers with four integrated risk management strategies: risk transfer, risk reduction, prudent risk taking, and risk reserves. While the risk transfer enables the poorest farmers to purchase a weather index insurance against drought, farmers can pay insurance premiums in cash or through insurance for assets (IFA) schemes that engage them in risk reduction activities. IFA schemes are built into government safety net programmes or World Food Programme food assistance for assets (FFA) initiatives. Additionally, individual or group saving enable farmers to build a financial base. Providing a self-insurance for communities, group savings can be loaned to individual members with particular needs (R4 2015).

\section{Client Value}

Ensuring that coverage is reliable and that critical risks are not under-insured is critical for the take up and success of insurance products that target the poor (Schäfer and Waters 2016). Bundling the insurance product, where appropriate, with additional 
services that are valuable to the client and the active reduction of basis risk, which remains a challenge for index products, were found as effective means to increase client value. SANASA in Sri Lanka is a good example for adding client value through bundling with additional services. The unique part of their index-based crop insurance product is that it is bundled with other covers like accidental death and hospitalisation which catered to various needs of the farmers and offered a good coverage for both production and livelihood risks (Prashad and Herath 2015).

\section{Affordability}

Most insurance-related approaches targeting poor and vulnerable people or countries have not been started and performed without some form of financial support, often in the form of premium support (Vivideconomics et al. 2016). Affording risk-based premiums remains a major challenge for this target group, and measures to increase the affordability of products are paramount to the success of insurance schemes. Finding solutions for this challenge is the precondition for establishing solidarity and human-rights-oriented insurance schemes that respond to concerns of equity (Schäfer and Waters 2016). When applied, premium support should always be smart in a way that it's reliable, flexible and long term, that distorts incentives as little as possible, and that makes the client aware of the true risk costs.

\section{Accessibility}

Efficient and cost-effective delivery channels that require minimum input but ensure a widespread reach are key for reaching a large client base and scale (Schäfer and Waters 2016). One way to achieve this can be by building on natural aggregators, such as associations, cooperatives, mutuals, federated self-help groups, and savings and credit groups, which have established successful and trusted delivery mechanisms and align the insurance scheme with the local context. Investing in tech-leveraged secure client identification and targeting as well as payment systems to reduce fraud and improve the timeliness of payouts were identified as success factors by the case study analysis. Moreover, it proved successful to utilise social protection programmes, where appropriate, to implement large-scale development of insurance for the poor and vulnerable.

\section{Participation, Transparency and Accountability}

Target group ownership and trust are essential for the effective use of insurance as a risk management tool. It is crucial to include the insured and beneficiaries in the design and implementation of insurance solutions and disaster risk reduction activities to ensure products truly work. Participatory approaches to product development can create trust, help with capacity building and make sure that the insurance actually meets the real needs of people at risk, thus creating client value. The case study results showed that it is important to actively support and build partnerships, networks and communication channels that allow for inclusive and meaningful involvement of the poor and vulnerable (Schäfer and Waters 2016). Organisations and structures that have deep roots within the local context are favourable partners. Schemes moreover need to ensure that the design and implementation processes are transparent and accountable. An effective monitoring and evaluation framework that measures out- 
puts, outcomes and impacts to ensure that the insurance schemes actually reach and benefit poor and vulnerable people is crucial.

\section{Sustainability}

Safeguarding financial, social and ecological sustainability is crucial for the longterm success of insurance schemes. This includes providing a long-term perspective on project planning and financing as setting up insurance schemes is a multi-year effort. Reliable flows of money accompanied by a long-term perspective helps to create a safe environment for key actors to engage in. It also involves making sure that insurance schemes do not incentivise practices that are not environmentally sustainable and incentivising risk reduction and prevention through the design of the insurance scheme, including risk-based premiums. From a social perspective, ensuring the participation and inclusion of women in climate risk insurance policy and programming is key (Schäfer and Waters 2016).

\section{Enabling Environment}

An enabling environment is a set of interrelated legal, organisational, fiscal, informational, political and cultural conditions that facilitate the successful development and implementation of an insurance scheme. Although the criteria for an enabling environment will be inevitably contextual, it is vital to actively build an enabling environment that accommodates and fosters pro-poor insurance solutions. Key factors of an enabling environment include capacity-building of key stakeholders, appropriate regulatory framework, strong, long-term partnerships and availability of data and technology (Schäfer and Waters 2016). First, capacity building is needed to improve the financial and insurance literacy and risk awareness of the insured, local insurers, distribution channels and governments. In the context of pro-poor insurance solutions it is important to use capacity building tools that respond to the needs of the target group and are suitable to educate clients with low written literacy about the complexity of index insurance. Second, successful insurance schemes need functioning regulatory and legal frameworks that govern the market, support the effective functioning of the scheme and allow growth by actively working with national governments and regulatory agencies. Third, strong, long-term partnerships, in particular public-private partnerships, which foster a clear allocation of roles is an important component of an enabling environment. The Index-Based Livestock Insurance Project (IBLIP) in Mongolia was first introduced in 2006 and provides herders with insurance through partnering with local private insurance companies. Insurance protects herders from climate-related losses to their livestock. With IBLIP there is a risk-layering approach to holistic risk management, combining self-insurance, market based insurance and a social safety net. Herders only bear the costs of small losses that do not affect the viability of their business; larger losses are transferred to the private insurance industry and the final layer of catastrophic loss is borne by the Government of Mongolia. The combination of the public disaster response product (a social safety net for herders offered by the government) and the private base insurance product (commercial product sold by private companies) proved to be highly successful for IBLIP. Fourth, freely accessible data and technology as well as hazard/weather monitoring 
infrastructure are essential for effective and efficient design and implementation as well as for ensuring the uptake, distribution and payout of insurance products.

\subsection{Conclusions}

In this chapter we established that the potential contribution of insurance as a navigational tool around adaptation frontiers can be conceptualised around three different ways: First, through facilitating the exploration of adaptation frontiers by contributing to a framework for signalling the magnitude, location, and exposure to climaterelated risks and providing signals when adaptation limits are approached. Second, by supporting actors in moving away from adaptation limits by incentivising risk reduction and creating a space for climate-resilient development. Third, by aiding actors in remaining in the tolerable risk space by facilitating financial buffering as part of contingency approaches. The conceptual debate around adaptation frontiers-including limits to adaptation-has been connected to the UNFCCC Loss and Damage discussions both in political and academic terms (e.g. Dow et al. 2013b). Given the potential contribution that insurance offers, this calls for a comprehensive reflection of insurance as part of the Loss and Damage policy space. Enhancing the international cooperation around the aspect of insurance as a climate risk management tool would allow to move forward several important aspects of the L\&D debate, even in the absence of consensus around the different political stands of Parties e.g. the distributive and compensatory justice considerations of increasing climate impacts (Schinko et al. 2018 in this book).

We see, however, that insurance in market terms against the risks of climate change possesses several limitations. Among others these are limited insurability against some climate risks, the inability to cover events on a full loss basis, affordability issues as climate change impacts drive loss expectations. Moreover, reduced insurance demand can be a result of clients discounting rare events psychologically. We therefore suggest the embedding of insurance in a comprehensive climate risk management approach accompanied by other risk reduction and management strategies as key principle for any international cooperation approach to respond to climate change impacts. Moreover, client value, the accessibility, affordability and sustainability of products, participation and transparency, as well as an accommodating enabling environment are key principles described in this chapter. We propose that risk transfer instruments like insurance need to comply with these principles in order to approach their potential as navigational tool around adaptation frontiers for developing countries. 


\section{References}

Adger WN, Dessai S, Goulden M et al (2009) Are there social limits to adaptation to climate change? Clim Change 93(3-4):335-354

ARC (2015) Accelerating action to resilience. Factsheet. http://www.africanriskcapacity.org/docu ments/350251/371107/A2R+EN.pdf. Accessed 20 April 2017

Arent DJ, Tol RSJ, Faust E et al (2014) Key economic sectors and services. In: Climate change 2014: impacts, adaptation, and vulnerability. Part A: global and sectoral aspects. In: Field CB et al (eds) Contribution of working group II to the fifth assessment report of the intergovernmental panel on climate change. Cambridge University Press, Cambridge, United Kingdom and New York, NY, USA, pp 659-708

Barnosky AD, Hadly EA, Bascompte SJ et al (2012) Approaching a state shift in earth's biosphere. Nature 486:52-58

Barrett CB, Barnett BC, Carter MR et al (2007) Poverty traps and climate risk: limitations and opportunities of index-based risk financing. IRI Technical Report No. 07-02. http://barrett.dyso n.cornell.edu/Papers/WP_Poverty_IRItr0702.pdf. Accessed 24 April 2017

Bertram-Hümmer V, Kraehnert K (2015) Does index insurance help households recover from disaster? Evidence from IBLI Mongolia. DIW Berlin Discussion Papers No. 1515. https://www.di w.de/documents/publikationen/73/diw_01.c.518175.de/dp1515.pdf. Accessed 24 April 2017

Bouwer L, Aerts JCJH (2006) Financing climate change adaptation. Disasters 30:49-63

Botzen WJW, van den Bergh JCJM (2008) The insurance against climate change and flooding in the Netherlands: present, future, and comparison with other countries. Risk Anal 28(2):413-426

Cai H, Chen Y, Fan H et al (2015) The effect of microinsurance on economic activities: evidence from a randomized field experiment. Rev Econ Stat 97(2):287-300

CCRIF SPC (2010) Caribbean Governments receive US $\$ 12.8 \mathrm{M}$ insurance payout from CCRIF following passage of Tomas, 17 November. http://www.ccrif.org/news/caribbeangovernments-r eceive-us128m-insurance-payout-ccrif-following-passage-tomas. Accessed 24 April 2017

Chambwera M, Heal G, Dubeux C, Hallegatte S, Leclerc L, Markandya A, McCarl BA, Mechler R, Neumann JE (2014) Economics of adaptation. In: Climate change 2014: impacts, adaptation, and vulnerability. Part A: global and sectoral aspects. In: Field CB, Barros VR, Dokken DJ et al (eds) Contribution of working group II to the fifth assessment report of the intergovernmental panel on climate change. Cambridge University Press, Cambridge, United Kingdom and New York, NY, USA, pp 945-977

Churchill C (2006) Protecting the poor: a microinsurance compendium. International Labour Organization. http://www.munichre-foundation.org/dms/MRS/Documents/ProtectingthepoorAmicro insurancecompendium-FullBook.pdf. Accessed 20 April 2017

Cole S, Bastian GG, Vyas S et al (2012) The effectiveness of index based micro-insurance in helping smallholders manage weather-related risks. Working paper: EPPI Centre, Social Science Research Unit. http://r4d.dfid.gov.uk/pdf/outputs/systematicreviews/MicroinsuranceWeather-20 12ColeReport.pdf. Accessed 20 April 2017

Collier B, Skees J, Barnett B (2009) Weather index-insurance and climate change: opportunities and challenges in lower income countries. The Geneva Papers 34:401-424

Cousky C, Cook RM (2009) Climate change and risk management challenges for insurance, adaptation, and loss estimation. Discussion paper. Resources for the Future. http://www.rff.org/files/ sharepoint/WorkImages/Download/RFF-DP-09-03.pdf. Accessed 20 April 2017

de Bruin K, Dellink RB, Agrawala S (2009) Economic aspects of adaptation to climate change: integrated assessment modelling of adaptation costs and benefits. OECD Publishing, Paris

Dercon S (1996) Risk, crop choice, and savings: evidence from Tanzania. Econ Dev Cult Change 44(3):485-513

Dercon S, Hoddinott J, Tassew W (2005) Consumption and shocks in 15 Ethiopian villages, 1999-2004. J African Econ 14:559-585

Dow K, Berkhout F, Preston BL (2013a) Limits to adaptation to climate change: a risk approach. Environ Sustain 5(3-4):384-391 
Dow K, Berkhout F, Preston BL et al (2013b) Limits to adaptation. Nat Clim Change 3:305-307

G7 (2015) Leaders' Declaration G7 Summit, 7-8 June 2015. https://www.g7germany.de/Conten t/DE/Anlagen/G8_G20/2015-06-08-g7-abschluss-eng.pdf?_blob=publicationFile. Accessed 5 May 2017

G20 (2017) Annex to G20 Leaders Declaration G20 Hamburg Climate and Energy Action Plan for Growth. https://www.g20.org/Content/DE/_Anlagen/G7_G20/2017-g20-climate-and-energ y-en.pdf?_blob=publicationFile\&v=6. Accessed 23 August 2017

Greatrex H, Hansen J, Garvin S (2015) Scaling up index insurance for smallholder farmers: Recent evidence and insights. CCAFS Report No. 14 Copenhagen: CGIAR Research Program on Climate Change, Agriculture and Food Security (CCAFS). https://cgspace.cgiar.org/rest/bitstreams/3871 6/retrieve. Accessed 24 April 2017

Hellmuth ME, Osgood DE, Hess U et al (2009) Index insurance and climate risk: Prospects for development and disaster management. Climate and Society 2. Available from https://iri.col umbia.edu/wp-content/uploads/2013/07/Climate-and-Society-Issue-Number-2.pdf. Accessed 24 April 2017

Hertwig R, Barron G, Weber EU et al (2004) Decisions from experience and the effect of rare events in risky choice. Am Psychol Soc 15(8):534-539

Herweijer C, Ranger N, Ward R (2009) Adaptation to climate change: threats and opportunities for the insurance industry. The Geneva Papers 34:360-380

Hoff H, Warner K, Bouwer LM (2005) The role of financial services in climate adaptation in developing countries. Vierteljahrshefte zur Wirtschaftsforschung 74(2), 196-207. http://dx.doi.o $\mathrm{rg} / 10.3790 / \mathrm{vjh} .74 .2 .196$

Hoppe P, Gurenko E (2006) Scientific and economic rationales for innovative climate insurance solutions. Clim Policy 6(6):607-620

IPCC (2012) Managing the risks of extreme events and disasters to advance climate change adaptation. In: Field CB, Barros V, Stocker TF (eds) A special report of working groups I and II of the intergovernmental panel on climate change. Cambridge University Press, Cambridge, UK, and New York, NY, USA

IPCC (2014) Climate change 2014: impacts, adaptation, and vulnerability. Part A: global and sectoral aspects. In: Field CB, Barros VR, Dokken DJ et al (eds) Contribution of working group II to the fifth assessment report of the intergovernmental panel on climate change. Cambridge University Press, Cambridge, United Kingdom and New York, NY, USA

Islam M, Sallu S, Hubacek K et al (2014) Limits and barriers to adaptation to climate variability and change in Bangladeshi coastal fishing communities. Marine Policy 43:208-216

Janzen S, Carter M (2013) The impact of microinsurance on asset accumulation and human capital investments: evidence from a drought in Kenya. Microinsurance Research Paper 31. http://bit.ly/ 2gbWzrP. Accessed 24 April 2017

Jensen ND, Barrett CB, Mude A (2015) The favourable impacts of index-based livestock insurance: evaluation results from Ethiopia and Kenya. ILRI Research Brief 52. https://cgspace.cgiar.org/b itstream/handle/10568/66652/ResearchBrief52.pdf?sequence=1. Accessed 25 March 2017

Klein RJT, Midgley GF, Preston BL, Alam M, Berkhout FGH, Dow K, Shaw MR (2014) Adaptation opportunities, constraints and limits. In: Field CB, Barros, VR, Dokken DJ, Mastrandrea MD, Mach KJ, Bilir TE, Chatterjee M, Ebi KL, Estrada YO, Genova RC, Girma B, Kissel ES, Levy AN, MacCracken S, Mastrandrea PR, White LL (eds) Climate change 2014: impacts, adaptation, and vulnerability. Part B: regional aspects. Contribution of working group II to the fifth assessment report of the intergovernmental panel on climate change. Cambridge University Press, Cambridge, United Kingdom and New York, NY, USA, pp 899-943

Klinke A, Renn O (2002) A new approach to risk evaluation and management: risk-based, precaution-based, and discourse-based strategies. Risk Anal 22:1071-1094

Kunreuther HC (1996) Mitigating disaster losses through insurance. J Risk Uncertainty 12(2-3):171-187 
Kunreuther HC, Michel-KEO (2008) Climate change, insurability of large-scale disasters, and the emerging liability challenge. http://scholarship.law.upenn.edu/cgi/viewcontent.cgi?article=1283 \&context=penn_law_review. Accessed 20 March 2017

Kunreuther HC, Pauly M (2004) Neglecting disaster: why don't people insure against large losses? J Risk Uncertainty 28(1):5-21

Kousky C, Cooke R (2012) Explaining the failure to insure catastrophic risks. The Geneva papers on risk and insurance-issues and practice 37(2):206-227

Lester R (2014) Insurance and inclusive growth. Policy Research Working Paper No. 6943. The Word Bank

Linnerooth-Bayer J, Bals C, Mechler R (2010) Insurance as part of a climate adaptation strategy. In: Hulme M, Neufedlt H (eds) Making climate change work for is. Cambridge University Press, Cambridge, pp 340-366

Linnerooth-Bayer J, Surminski S, Bouwer LM, Noy I and R Mechler (2018) Insurance as a response to loss and damage? In: Mechler R, Bouwer L, Schinko T, Surminski S, Linnerooth-Bayer J (eds) Loss and damage from climate change. Concepts, methods and policy options. Springer, Cham, pp 483-512

Luxbacher K, Goodland A (2010) Building resilience to extreme weather: index-based livestock insurance in Mongolia. World Resources Report Case Study. http://www.wri.org/sites/default/fi les/wrr_case_study_index_based_livestock_insurance_mongolia_pdf. Accessed 21 April 2017

Madajewicz M, Tsegay AH, Norton M (2013) Managing risks to agricultural livelihoods: impact evaluation of the Harita Program in Tigray, Ethiopia, 2009-2012. http://www.oxfamamerica. org/static/media/files/Oxfam_America_Impact_Evaluation_of_HARITA_2009-2012_English. pdf. Accessed 20 April 2017

Mechler R, Schinko T (2016) Identifying the policy space for climate loss and damage. Science 354(6310):290-292

Mechler R et al (2018) Science for loss and damage. Findings and propositions. In: Mechler R, Bouwer L, Schinko T, Surminski S, Linnerooth-Bayer J (eds) Loss and damage from climate change. Concepts, methods and policy options. Springer, Cham, pp 3-37

Melecky M, Raddatz C (2011) How Do governments respond after catastrophes? Natural-Disaster Shocks and the Fiscal Stance. World Bank Policy Research Working Paper No. 5564. http://bit.l y/2eLjDdZ. Accessed 25 April 2017

Mobarak AM, Rosenzweig MR (2013) Informal risk sharing, Index insurance, and risk taking in developing countries. Am Econ Rev: Papers Proc 103(3):375-380

Monnereau I, Abraham S (2013) Limits to autonomous adaptation in response to coastal erosion in Kosrae, Micronesia. Int J Global Warming 5(4):416-432

Okonjo-Iweala N, Thunell L (2015) African countries turn to insurance to safeguard against climate change. The Guardian, 7 October. http://www.theguardian.com/global-development/2015/oct/0 7/african-risk-capacity-agency-au-climate-changeadaptation-insurance. Accessed 24 April 2017

Oppenheimer M, Campos M, Warren R, Birkmann J, Luber G, O’Neill B, Takahashi K (2014) Emergent risks and key vulnerabilities. In: Field CB, Barros VR, Dokken DJ, Mach KJ, Mastrandrea MD, Bilir TE, Chatterjee M, Ebi KL, Estrada YO, Genova RC, Girma B, Kissel ES, Levy AN, MacCracken S, Mastrandrea PR, White LL (eds) Climate change 2014: impacts, adaptation, and vulnerability. Part A: global and sectoral aspects. Contribution of working group II to the fifth assessment report of the intergovernmental panel on climate change. Cambridge University Press, Cambridge, United Kingdom and New York, NY, USA, pp 1039-1099

Poundrik, S (2011). Disaster Risk Financing: Case Studies. Working Paper No. 23. EAP DRM KnowledgeNotes: Disaster Risk Management in East Asia and the Pacific. Washington, D.C.: The World Bank. Global Facility for Disaster Reduction and Recovery (GFDRR). http://www.documents.worldbank.org/curated/en/324451468026333428/pdf/604560 BRI0231R10BOX358322B01PUBLIC1.pdf. Accessed 20 August 2019

Prashad P, Herath R (2015) Introducing index based crop insurance in Sri Lanka and improving client value. http://www.impactinsurance.org/practitioner-lessons/sanasa. Accessed 20 April 2017

Preston B, Dow K, Berhout F (2014) The climate adaptation frontier. Sustainability 5(3):1011-1035 
R4 (2015) R4 Rural Resilience Initiative quarterly report, January-March 2015. http://policy-pra ctice.oxfamamerica.org/static/media/files/R4_Report_Jan_Mar15_WEB.pdf. Accessed 20 April 2017

Ranger N, Fisher S (2012) The challenges of climate change and exposure growth for disaster risk management in developing countries. Report produced for the Government Office of Science, Foresight project 'Reducing Risks of Future Disasters: Priorities for Decision Makers'. https://www.gov.uk/government/uploads/system/uploads/attachment_data/file/287434/121305-climate-change-exposure-growth-for-disaster-risk.pdf. Accessed 4 March 2017

Ranger N, Niehörster F (2012) Deep uncertainty in long-term hurricane risk: scenario generation and implications for future climate experiments. Glob Environ Change 22(3):703-712

Rejda GE, McNamara MJ (2017) Principles of risk management and insurance, 13th edn. Pearsons, Harlow

Reyes CM, Gloria RAB, Mina CD (2015) Targeting the agricultural poor: The case of PCIC's special programs. http://dirp3.pids.gov.ph/webportal/CDN/PUBLICATIONS/pidsdps1508.pdf. Accessed 24 April 2017

Rockström J, Steffen W, Noone K (2009) A safe operating space for humanity. Nature 461:472-475

Schäfer L, Waters E, Kreft S, Zissener M (2016) Making climate risk insurance work for the most vulnerable. Policy Report No. 1. United Nations University Institute of Environment and Human Security (UNU-EHS), Bonn. http://www.climate-insurance.org/fileadmin/mcii/documents/MC II_PolicyReport2016_Making_CRI_Work_for_the_Most_Vulnerable_7GuidingPrinciples.pdf. Accessed 20 March 2017

Schäfer L, Waters E (2016) Climate risk insurance for the poor and vulnerable. How to effectively implement the pro-poor focus of InsuResilience. http://www.climate-insurance.org/fileadmin/mc ii/documents/MCII_2016_CRI_for_the_Poor_and_Vulnerable_full_study_lo-res.pdf. Accessed 20 March 2017

Schinko T, Mechler R, Hochrainer-Stigler S (2018) The risk and policy space for loss and damage: integrating notions of distributive and compensatory justice with comprehensive climate risk management. In: Mechler R, Bouwer L, Schinko T, Surminski S, Linnerooth-Bayer J (eds) Loss and damage from climate change. Concepts, methods and policy options. Springer, Cham, pp $83-110$

Sharoff J, Diro R, Mccarney G, Norton M (2015) R4 rural resilience initiative in Ethiopia. http://www.climate-services.org/wp-content/uploads/2015/09/R4_Ethiopia_Case_Stu dy.pdf. Accessed 24 April 2017

Skees JR, Barnett BJ, Murphy AG (2008) Creating insurance markets for natural disaster risk in lower income countries: the potential role for securitization. Agric Financ Rev 68:151-157

Skees JR, Collier B (2008) The Potential of weather index insurance for spurring a green revolution in Africa. Working paper, GlobalAgRisk, Inc. Lexington, Kentucky. https://www.uky.edu/Ag/A gEcon/pubs/resWeatherAGRA04.pdf. Accessed 24 April 2017

Stahel WR (2003) The role of insurability and insurance. The Geneva Papers on Risk and Insurance 28(3):374-381

Surminski S, Oramas-Dorta D (2013) Do flood insurance schemes in developing countries provide incentives to reduce physical risks? Centre for Climate Change Economics and Policy Working Paper No. 139. http://www.cccep.ac.uk/wp-content/uploads/2015/10/WP119-flood-insurance-sc hemes-developing-countries.pdf. Accessed 20 April 2017

Surminski S, Bouwer LM, Linnerooth-Bayer J (2016) How insurance can support climate resilience. Commentary in: Nat Clim Change 6:333-334

Vivideconomics Surminski Consulting, Consulting Callund (2016) Understanding the role of publicly funded premium subsidies in disaster risk insurance in developing countries. Evidence on Demand, UK

von Peter G, von Dahlen S, Saxena S (2012) Unmitigated disasters? New evidence on the macroeconomic cost of natural catastrophes. BIS Working Papers No. 394. Monetary and Economic Department. http://www.bis.org/publ/work394.pdf. Accessed 25 April 2017 
Warner K, Spiegel A (2009) Climate change and emerging markets: the role of the insurance industry in climate risk management. In: Liedtke M (ed) The Geneva Reports. Risk and Insurance Research. The Insurance Industry and Climate Change-Contribution to the Global Debate, pp 83-94

Warner K, Kreft S, Zissener M et al (2012) Insurance solutions in the context of climate change related loss \& damage. Policy Brief No. 6. United Nations University Institute of Environment and Human Security (UNU-EHS), Bonn. http://www.climate-insurance.org/fileadmin/mcii/doc uments/20121112_MCII_PolicyBrief_2012_screen.pdf. Accessed 1 March 2017

Warner K, van der Geest K, Kreft S (2013) Pushed to the limits: Evidence of climate change-related loss and damage when people face constraints and limits to adaptation. Report no. 11. United Nations University Institute of Environment and Human Security (UNU-EHS), Bonn

Warner BP, Kuzdasa C, Yglesiasd MG et al (2015) Limits to adaptation to interacting global change risks among smallholder rice farmers in Northwest Costa Rica. Glob Environ Change 30:101-112

Open Access This chapter is licensed under the terms of the Creative Commons Attribution 4.0 International License (http://creativecommons.org/licenses/by/4.0/), which permits use, sharing, adaptation, distribution and reproduction in any medium or format, as long as you give appropriate credit to the original author(s) and the source, provide a link to the Creative Commons license and indicate if changes were made.

The images or other third party material in this chapter are included in the chapter's Creative Commons license, unless indicated otherwise in a credit line to the material. If material is not included in the chapter's Creative Commons license and your intended use is not permitted by statutory regulation or exceeds the permitted use, you will need to obtain permission directly from the copyright holder.

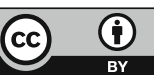

